\title{
Purification, Not Otherwise Specified
}

National Cancer Institute

\section{Source}

National Cancer Institute. Purification, Not Otherwise Specified. NCI Thesaurus. Code C113067.

Any isolation method not otherwise specified. 